\title{
The role and significance of regional policy in Europe ${ }^{1}$
}

\author{
Michał Konopski \\ Institute of Geography and Spatial Organization \\ Polish Academy of Sciences \\ Twarda 51/55, 00-818 Warsaw, Poland \\ konopski@twarda.pan.pl
}

\begin{abstract}
The EU regional policy has been formed with the intention to reduce regional disparities, foster balanced development and promote equal opportunities for all. The aim of this paper is to present the evolution of regional policy and its assumptions since the 1950s. The article comprises synthesis and evaluation of the role and significance of regional policy regarding the functioning of Europe's regions struggling with social, economic and environmental issues. The study was based on materials examining the subject of regional policy in Europe, with special attention to Poland's case, revealing its strengths and weaknesses.
\end{abstract}

Keywords: regional policy, cohesion policy, programming period, structural funds, regional disparities, regional development

\section{Introduction}

Seeking a solution for regional socio-economic issues has for a long time been a significant component of state intervention in most of Europe. For the purpose of political declarations and scientific publications it has been called 'regional policy', although the understanding of this term differs to a great extent between various authors. Regional policy assumes intervention designed to amend the territorial structure in economic and social dimension in accordance with a given direction. In order to achieve its objectives, a policy can stimulate or restrict the development of regions/areas (Artobolevskiy 1997).

In principle, regional policy can be examined on two main levels. The first one is regional policy of the European Union, to which vast majority of this article will be dedicated. However, the national regional policy (a separate policy of some EU members) cannot be omitted, as it had

\footnotetext{
1 This paper has been developed under the Scientific Platform project Detecting Territorial Potential and Challenges led by Nordregio, Sweden. It has been financed by the ESPON 2013 Programme and its financial support is gratefully acknowledged. Texts, maps and conclusions stemming from research projects under the ESPON programme presented in this paper do not necessarily reflect the opinions of the ESPON Monitoring Committee. (C) ESPON, 2014.
} 
been implemented in each Member State prior to the establishment of the European Union. For instance, the regional policy in the UK was commenced as a response to the economic depression of the 1930s. Furthermore, such intervention can be developed at the state level as inter-regional policy or intra-regional policy when created at the regional level. It must be stated that in the past the European policy was often modeled on the national policy. These two activities present various spatial dimensions, i.e. the EU policy is formed with an approach of perceiving Europe as a single system made up of regions featuring different levels of socio-economic performance. On the other hand, the regional policy created at national level is of a smaller spatial scale, more focused on the region itself and its relations to other parts of a country. Such policy document has, however, invaluable qualities as regional policymakers, who are involved in its formation, simply know their region best, along with its endogenous potential, current issues and challenges. Policymakers at the regional level are increasingly aware that their region is becoming a part of a wider European territory (ESPON Malmo Report, 2010) and thus, they understand the necessity for policy at the national/regional level to be consistent with and complementary to the EU policy as these two have in fact shared goals and objectives.

When examining EU regional policy in the subject literature, one can find various terms that might be confusing if a researcher is not aware of the slight differences between them. Thus, there is a Structural policy, which might be regarded as a traditional concept describing the intervention of the European Community (and since 1993 - the European Union). This term has been used since 1957 as derived from structural funds, which are the main instruments of regional policy. On the other hand, there is a Regional policy, focused on increasing coherence of economic and social situation in the European Union, with its primary task being financial aid for the regions. Finally, Cohesion policy, the youngest of the three, relates to the primary objective of the intervention, which is to reduce disparities in the Union. Practically, however, these terms are often used interchangeably, and therefore one can assume that regional, structural and cohesion policies of the European Union have the same goal - to smooth out the economic differences between the regions of the European Union and as a result - between their inhabitants (www.funduszeeuropejskie.gov.pl).

The aim of this paper is to briefly present the evolution of regional policy in Europe, including its prime objectives and assumptions since the birth of the idea of Common Europe. The article comprises a synthesis and a reflection on the role and significance of regional policy in the functioning of Europe's regions facing new challenges and struggling with current social, economic and environmental issues that have emerged in the 21 st century. This paper also attempts to evaluate the EU's regional policy as a tool designed for counteracting contemporary problems, intended to contribute to a more balanced development of regions and to overcoming of the disparities that have arisen between them. The study was based on a review of available materials examining the issue of regional policy in Europe, capturing the subject matter from diverse points of view as well as revealing the strengths and weaknesses of the regional policy.

\section{Regional policy in Europe - the early years}

The Rome Treaty of 1957 initiated the notion of promoting a 'harmonious development of economic activities' in the European Community. From this premise the origins of regional policy derive. This assumption was to a great extent motivated by the fact that the founders of the European Economic Community (EEC) were at approximately comparable levels of development apart from southern 
Italy. For this reason, a common aim was set to reduce the existing regional disparities. In order to achieve such objective, the European Investment Bank (EIB) was established in 1958, becoming the provider of funds at low interest rates for the less developed regions. During the same year the first two structural funds were formed: the European Social Fund (ESF) and the European Agricultural Guidance and Guarantees Fund (EAG) (www.ec.europa.eu). Since then, the regional policy went through several stages (see Fig. 1). The beginning of a modern regional policy goes as far back as the 1960s, when, in the period of prosperity and stable economic growth, emerged an aspiration to balance the development based on the principle of equality. Concurrently, regional policy at national level was developed to counteract specific problems of those times. The main issues of concern to regional policymakers across Western Europe were underdevelopment and depopulation in rural areas, aiming at equalizing the unevenly distributed standards of living, infrastructure and employment (Bachtler, Yuill 2001). In practice, the system of European policy applied instruments of public revenue redistribution in the form of transfers from richer to poorer regions. At that time the regional policy of the Community was of a restricted scale of operation as it merely provided financial support to member states for pursuing their national policies (Faludi 2009).

In order to rationalize and improve the mechanism in the field of policy implementation and management, the Directorate-General for Regional Policy of European Commission was created. Subsequently, the existing approach was modified in the period of structural and technological changes of the 1970s and 1980s. The main objective of the regional policy was economic convergence consisting in mitigation of increasing unemployment effects (Olechnicka, Wojnar 2013). This shift was caused by the necessity to adopt the policy to the changing reality of this period, which in the Western European countries was marked by energy crisis and collapse of traditional industry, consequently leading to numerous social and economic issues. Moreover, at that time the EEC expanded by three new members (United Kingdom, Ireland and Denmark) having, on the one hand, added their own structural problems, on the other, however, having brought along the experience in solving various issues related to regional development. Particularly, United Kingdom was characterized by a long tradition in the field of creating regional policy. According to Faludi (2009) funding for European regional policy became available after this enlargement of 1973.

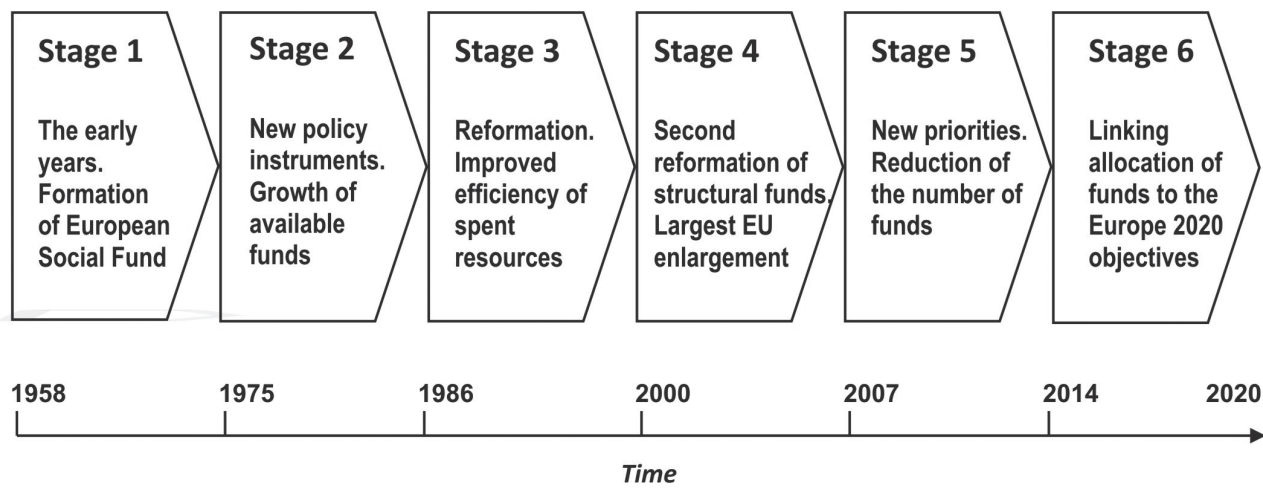

Fig. 1. Stages of EU regional policy formation. Source: Own elaboration. 


\section{New instruments of intervention}

Despite intensive efforts and available resources, the regional policy in its initial phase had not brought anticipated results. In many cases allocating financial means in the regions lagging behind proved to be an insufficient development impulse, and so the notion of convergence often remained a strictly theoretical concept. A critical decision in shaping the improved regional policy was the foundation of the European Regional Development Fund (ERDF) in 1975 with the assumption of enhancing economic and social cohesion of the EEC, the emphasis being placed on mitigating the differences among regions.

A series of new challenges for regional policy was induced by the accession of Greece (in 1981) as well as Spain and Portugal (1986). The new member states were characterized by significant regional disparities (resulting, among others, in vast differences in the GDP levels) in comparison to the old ones, and required immense financial help. In order to reduce vast regional polarization the Integrated Mediterranean Programs were implemented from 1985 onwards, supporting the development of tourism, agriculture, as well as small and medium enterprises in regions in need. Such a programmatic approach was introduced by Jacques Delors and was modeled on French national policy (Faludi 2009). Another crucial step in reshaping regional policy towards a more efficient tool for a balanced regional development across Europe was the formation of the Assembly of European regions (1985). Its main objective encompasses creation and enforcement of political authorities representing regional institutions in the joint institutions of European Union, but also improving interregional cooperation (www.ec.europa.eu).

A turning point for contemporary regional policy in Europe occurred in 1986 (see Fig. 1.) with the adaptation of the Single European Act. There emerged a need to cope with the changes after the enlargement. At this time the idea of forming a single market was introduced as well as the concept of cohesion policy. One of the basic assumptions of the Single European Act was to match the instruments of regional policy with the common objective to accomplish 'equal, balanced and sustainable development', later included in the Treaty of European Community (Consolidated version of The Treaty on European Union and of The Treaty Establishing The European Community, Article 2). This stage in the EU's regional policy evolution was characterized by the significant reform of structural funds as these were doubled and reached $25 \%$ of the community's budget in 1992. More emphasis was also put on improving the efficiency of resource spending. In the same year (1992), the Cohesion Fund was founded, constituting another pillar of regional policy. By the formation of Committee of the Regions (CoR) consisting of local and regional government representatives it was possible to coordinate the assumptions of EU's regional policy with the national policies and regulations of the member states (www.ec.europa.eu). From that point onwards the interventions within regional policy at the European and national levels were expected to become complementary for a more efficient mitigation of regional disparities.

\section{A change of approach}

In the process of shifting from classical to contemporary regional policy there has been an increasing spatial focus on all areas, as opposed to problem areas and thus emerged a more holistic approach aiming at European cohesion. The term mentioned, cohesion - without a doubt - can be considered to be one of the pillars constituting modern regional policy and at the same time one of the most 
frequently used phrases in current policies conducted within the European Union. This keyword is considered as a relatively new one, as it was first introduced in the Single European Act of 1986. The document emphasizes the need to enhance the social and economic cohesion of the European Community with the objective to level out regional disparities and avoid their potential growth. The concept of cohesion is rooted in the Maastricht Treaty establishing the European Union (1992). Moreover, as the Cohesion Fund was formed, cohesion has become one of the leading directions of the European Union policies, having social, economic and territorial dimensions (Gorzelak 2012). At this point it must be stated that there are numerous definitions of cohesion and to some extent this term remains vague. Furthermore, the idea of territorial cohesion is considered as weakly rooted intellectually comparing with, for instance, social cohesion (Hague, 2005). Such opinion was also shared by Poverari and McMaster (2005), who claimed that 'definitions of cohesion - economic and social but also and even more so territorial - are ambiguous'. It was upon the initiative of Michel Barnier, the French Minister of European Affairs, that territorial cohesion was formally mentioned for the first time in the Treaty of Amsterdam (Faludi 2009) signed in 1997, which was a document introducing substantial changes to the Treaty of Maastricht.

The beginning of the 21st century initiated vivid debate concerning the future of regional policy and resulted in redefinition of its objectives, priorities and instruments. This was especially crucial in the light of the biggest EU enlargement that was set for 2004 and such reform was necessary as the EU territory was to include numerous underdeveloped regions. The new paradigm of the regional policy is therefore characterized by taking into consideration qualitative aspects of territorial diversity in the process of its formation. The new priorities include competitiveness and economic coherence based on specific territorial potential of a given region (Olechnicka, Wojnar 2013). Furthermore, there is an evident paradigm shift in such aspects as conceptual basis (from Industrial location theories to Learning region theories), policy aims (from Equality or efficiency to Equality and efficiency) and objectives (from Employment creation by increased investment to Increased competitiveness), sphere of action (from narrow, economic/industrial to broad, multi-sectoral), policy development (from centralized to collective in accordance with the notion of decentralization and regionalization). A significant change also concerned the timescale, from open-ended to multi-annual planning periods (Bachtler, Yuill 2001). Furthermore, the European Union gradually increases the role of territory as a crucial subject of regional policy, involving measures geared at implementation of mechanisms coordinating various elements of development policy (Chudy-Hyski 2009). Officially, territorial cohesion was included as one of the objectives in the Constitutional Treaty of 2004.

\section{The role and significance of regional policy}

The regional policy (also referred as Cohesion Policy) of the European Union has been formed with the intention to reduce structural disparities between EU regions, foster balanced development throughout its territory and promote equal opportunities for all. In practical terms it seeks to support job creation, enhance competitiveness and economic growth, as well as improve quality of life, maintaining the notion of sustainable development. The assumptions of EU's regional policy in its current shape are realized by means of various financing operations, mainly through the Structural Funds and the Cohesion Fund.

The role and significance of this policy is immense, taking into consideration its scale, as more than one third of the EU's budget is devoted to its implementation. Apart from the evident tangible 
benefits in the form of substantial input, this policy also brings symbolic dimension as by enforcing the EU's regional policy, solidarity of the member states' with less developed countries and regions is expressed. The essential purpose of the regional policy assumes reduction of significant disparities among the EU's regions that continue to persist in terms of their economic, social and territorial performance. Not taking action towards such unfavorable polarization would undermine the cornerstones of the European Union (www.europa.eu).

The next section reviews characteristics of the three regional policy programming periods, which seem to have the greatest impact on the contemporary characteristics of the European Union's regions. Firstly, the 2000-2006 period, which has been completed a few years ago and its final evaluation has been already conducted. Secondly, the Cohesion Policy of 2007-2013, which has recently been completed and thus it is rather too early for carrying out its ultimate analysis or drawing unequivocal conclusions on its role and significance. Thirdly, the current programming period of 2014-2020, whose aims and assumptions are yet to be fulfilled.

\section{Regional Policy of 2000-2006. The biggest EU enlargement}

The regional policy of 2000-2006 has been implemented under the slogan "Making enlargement a success", as this period corresponded to the largest enlargement of the EU (10 new member states jointed the EU structures in May 2004). In March 2000 the Lisbon Strategy was formulated, shifting the EU's priorities towards growth, jobs and innovation. The preferences of cohesion policy were altered to reflect these assumptions. This was a critical point for the regional policy, because the enlargement significantly raised the disparities across Europe. Accession of the new member states has increased the EU's population by $20 \%$, but the GDP by only $5 \%$. Numerous regions of the new member states were also characterized by a significantly higher unemployment rate and serious demographic issues. This programming period was therefore to face challenges of unprecedented scale in numerous aspects, and, for instance, according to Poverari and McMaster (2005) the enlargements of the Union raise new challenges for the achievement of territorial cohesion in an EU of increased territorial disparities. The policy assumed three priority Objectives, two of which were financed by the European Regional Development Fund (ERDF). These are listed below:

- Objective 1: Development and structural adjustment of lagging-behind regions

- Objective 2: Economic and social conversion of areas with structural difficulties

The remaining, Objective 3, financed by the European Social Fund (ESF) was intended for adaptation as well as modernization of national policies to achieve complementary effect of the policies. Furthermore, the countries in the process of accession to the EU had at their disposal the following financial instruments:

- PHARE (Poland and Hungary: Assistance for Restructuring their Economies)

- ISPA (Instrument for Structural Policies for pre Accession)

- SAPARD (Special pre Accession Assistance for Agriculture and Rural Development)

- CARDS (Community Assistance for Reconstruction, Development and Stabilization).

With the total budget of $€ 235$ billion, it is estimated that the 2000-2006 programming period has contributed, in particular, to (ec.europa.eu):

- Creating 1.4 million jobs

- Constructing $2000 \mathrm{~km}$ of motorways

- Building $4000 \mathrm{~km}$ of rail lines 
- Gaining access to cleaner water by 14 million people

- Co-financing 38000 research projects

- Supporting over 800000 SMEs.

The figures above seem to indicate an immense role and significance of regional policy in Europe. There have, however, been arguments raised that 'the economic and physical impacts of the Structural Funds are widely debated and difficult to measure' (Poverari, McMaster 2005).

Despite the optimistic nature of the numbers above, the evaluation of EU policy contained in the Sapir Report (Sapir A. Et al. 2003) was less positive. According to its findings, in the field of cohesion it has been achieved at the Member States and macro-regional levels but not at the regional level. Furthermore, the assumptions of policy have been challenged regarding economic correlations as compensating financial transfers are good for cohesion but bad for growth. Thus, in the light of this argument it is not surprising that not all EU members are particularly enthusiastic about territorial cohesion (Hague 2005). Furthermore, concerning the policy structure - it is found to be too complex (Sapir Report Summary 2003).

\section{The case of Poland}

The new Member States, which joined the European Union during this programming period, have received immense financial means. The question is, however, to what extent are those resources consumed and adequately allocated with the eventual objective of contributing to regional development. The reliable statistics revealing the actual significance and need for allocating EU's funds might be the amount of expenditure financed by the EU structural funds per capita. In case of Poland, the mean amount of such expenditure in relation to one inhabitant was in the year of accession (2004) at the level of 25.6 PLN, whereas in 2011 it reached 982.4 PLN (fig. 2.) giving an overall growth of almost $4000 \%$ in 8 years (Misiąg, J., Misiąg, W., Tomalak 2013). The figures above signify an increasing adoption of the EU funds in terms of expenditure and surely the resulting investment would not take place without the instruments of regional policy.

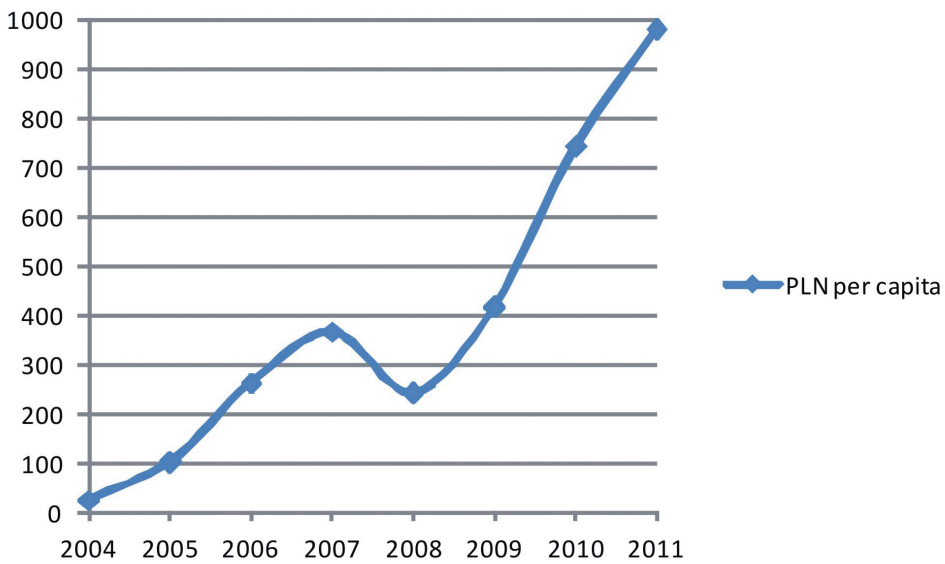

Fig. 2. Amount of expenditure financed by the EU structural funds per capita in Poland in 2004-2011 (in PLN). Source: own elaboration based on Misiąg, J., Misiąg, W., Tomalak M., 2013 


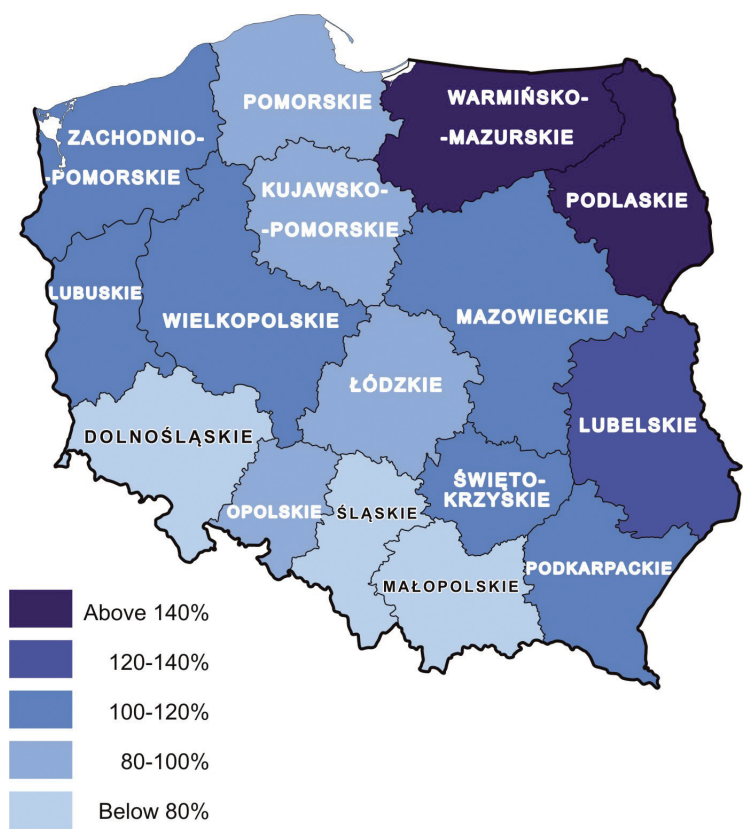

Fig. 3. Expenditure financed by the means from the EU budget in the years 2004-2011 in Poland, by voivodships (per capita, the mean value for Poland =100). Source: own elaboration based on Misiąg, J., Misiąg, W., Tomalak M., 2013

As evidenced by figure 3, the financial means coming from the EU, addressed to Poland, have in the years 2004-2011 mostly contributed to the expenditure of the least developed regions of eastern and north-eastern Poland (where the respective per capita expenditure exceeded $140 \%$ of the mean value for Poland). On the other hand, the resources of the EU budget have to the lowest extent contributed (below the mean value for Poland) to the expenditures of much more developed regions of southern Poland. This might provide evidence for adequate allocation of financial means within the EU's regional policy and proves their significance in the share of expenditure. The authors of a report dedicated to the assessment of the effectiveness of the European Union financial aid as an instrument of socio-economic cohesion and improvement of living conditions (Misiąg, J., Misiąg, W., Tomalak 2013) cite the statistics below, from which one may conclude that since the year 2004, through the projects financed from European funds, the following were built, established or modernized in Poland:

- More than $15500 \mathrm{~km}$ of roads, including $1325 \mathrm{~km}$ of motorways and expressways,

- More than $2100 \mathrm{~km}$ of railway lines,

- Approximately $34000 \mathrm{~km}$ of sewerage networks,

- Approximately $1100 \mathrm{~km}$ of water supply networks,

- More than 650 wastewater treatment plants,

- Over 1700 research laboratories,

- About 150000 new businesses and approximately 289000 new jobs.

As after 2004 the amount of financial resources addressed to Poland has been continuously increasing, so has the global crisis gradually affecting Polish economy. In terms of statistics, one could claim that the growing transfers from the EU budget have resulted in weakening Poland's economic growth (Misiąg, J., Misiąg, W., Tomalak 2013). Obviously, this is not the case as the global economic crisis 
has coincided with the first years after the accession to the EU. Moreover, there is concrete evidence that the instruments of EU's regional policy have in fact contributed to mitigating regional disparities across Europe. It is certain that the objectives of Poland's National Strategic Reference Framework (NSRF 2007-2013) will be achieved in terms of the GDP level per capita in relation to the mean level of GDP per capita for the EU-25 countries, namely $65 \%$, as a result of regional policy. However, at the same time other crucial assumptions of the NSRF, for instance workforce productivity (measured in the level of GDP per worker) as well raising the investment rate at the intended level will not be achieved despite the EU funds. Moreover, it is evidenced that the GDP level of the regions in eastern Poland has been increasing in the years 2004-2012 at a much slower rate in relation to other parts of the country (Misiąg, J., Misiąg, W., Tomalak 2013). At this point it must be stated that the eastern part of Poland has benefited from a dedicated program called "Development of Eastern Poland" and due to this fact has received incomparably bigger amount of EU funds. This proves that although the financial means, if allocated adequately may contribute to raising the standards of living (as these funds were invested, inter alia, in necessary technical infrastructure), however, enhancing the development potential of a given region still remains an issue and is a major challenge for regional policy.

\section{Regional Policy of 2007-2013. Focus on growth and jobs}

The main assumption for this programming period was to accomplish the goals of the Lisbon and Gothenburg Strategies. At that time 'the cohesion policy reinvented itself as an instrument of the Lisbon Strategy' (Faludi 2009). The general objective was to decrease economic and social differences throughout the EU and to seek the contribution of all regions and social groups to common economic development. The Cohesion policy, intended to support regional development of the EU comprised the structural part of the Strategies mentioned, and through national and regional development programs it enabled the accomplishment of the strategic goals. This programming period put emphasis on the less developed regions, which was especially significant to the new member states that joined the EU in 2007 (Bulgaria and Romania).

For the period 2007-2013 the European Union's regional policy was the EU's second largest budget item, with an allocation of $€ 348$ billion, of which $25 \%$ has been earmarked for research and innovation and $30 \%$ for environmental infrastructure and measures to combat climate change (europa.eu). At this point it must be emphasized that in comparison to the previous (2000-2006) programming period the budged has been increased by about a third. The EU's regional policy covered all European regions, although its regions fell into different categories, depending mostly on their economic situation. In the 2007-2013 funding period, the EU regional policy consisted of three objectives: Convergence, Regional competitiveness and employment, as well as European territorial cooperation (Fig.4.). These have superseded the Objectives 1, 2 and 3 of the previous policy. The instruments for pursuing the fulfillment of assumptions of regional policy consisted of European Regional Development Fund (ERDF), European Social Fund (ESF) and Cohesion Fund. By far the largest amount (282.8 billion euro, accounting for $81.5 \%$ ) of regional policy funding in this period was dedicated to the regions in the Convergence objective (see Fig. 4.). Its main assumption was to promote the conditions for the rise in growth factors that lead towards actual convergence of the least developed countries and regions of the EU. This objective referred to 84 regions in the 18 member countries encompassing 154 million people (31\% of EU27) and was addressed to Europe's poorest regions with gross domestic product per capita (GDP) below $75 \%$ of the EU average. Regional Policy 
projects within Convergence regions were supported by three European funds: the European Regional Development Fund (ERDF), the European Social Fund (ESF) and the Cohesion Fund. The objective of Regional competitiveness and employment was established with an intention to cover more well-off regions, which were not enfolded by the Convergence objective. Its main aim was to create jobs by promoting and making the regions concerned more attractive to businesses and investors. The funding was managed through either the ERDF or ESF and comprised 16\% of the EU's regional policy budget. The third objective, the European territorial cooperation, intended to enhance cross-border, transnational and interregional cooperation within the EU, accounting for the remaining $2.5 \%$ of the EU's regional policy budget, was exclusively funded through the ERDF.

Due to the fact that not all assumptions of the 2007-2013 programming period have been yet accomplished, it is difficult to conduct its final evaluation and to attempt reflecting on its concrete role and significance. It might be, however, expected, that due to increased budget implementation, the policy should result in more than satisfactory outcomes. As evidenced in respective literature, upon analyzing the impact of EU policy in Poland 'the funds of EU cohesion policy of 2007-2013 noticeably increased the investment freedom of Polish authorities (at national, regional and local levels) creating opportunities for more intense growth or improving life quality' (Kozak 2012). Once again, the Polish case proves that Poland's accession to the EU is not merely related to receiving and allocating funds, but also developing a new approach and "culture" in terms of managing public means (Misiąg, J., Misiąg, W., Tomalak 2013). Therefore, accession to the EU is to a great extent associated with imposing changes in mentality, particularly prescribed in the case of the new-member states originating from the former Eastern Bloc.

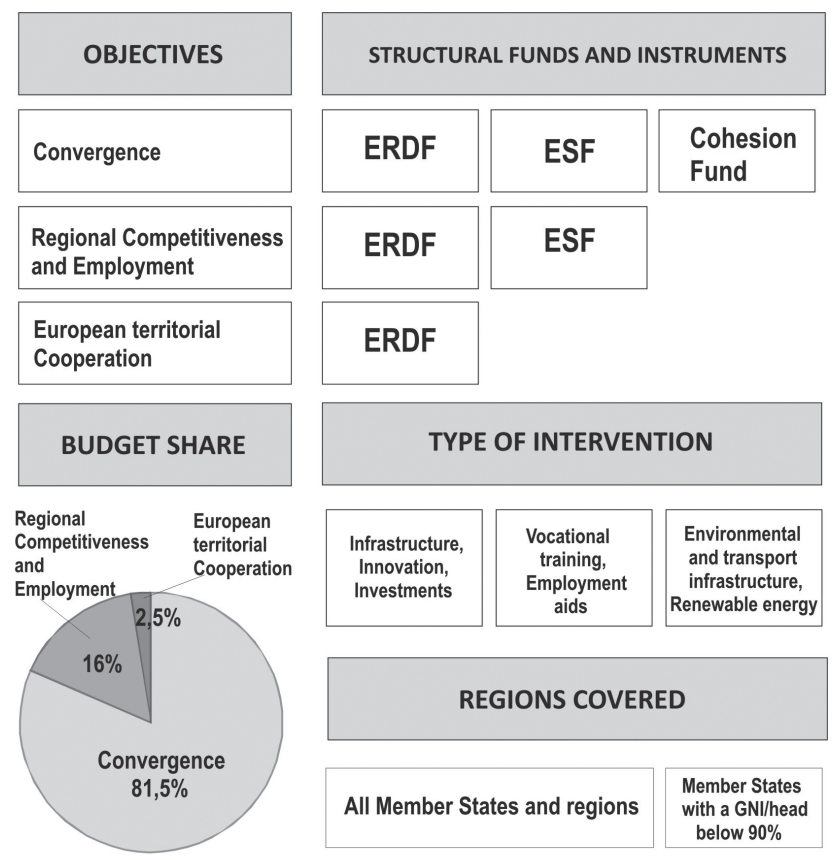

Fig. 4. Objectives, Structural Funds and Instruments as well as budget share of the 2007-2013 EU regional policy. Source: Own elaboration based on: Directorate-General for Regional and Urban Policy (ec.europa.eu) and Introduction to the Structural Funds 2007-2013, DG REGIO. Abbreviations are explained in the main text. 


\section{Regional Policy of 2014-2020. New challenges}

The EU's Cohesion Policy of 2014-2020 aims at promoting economic prosperity and social cohesion throughout the entire territory of the Union. Since the programming period of 2007-2013 a new objective of Territorial Cohesion was added, in order to achieve a more integrated, place-based approach. EU Cohesion Policy 2014-2020 is anticipated to contribute to the EU 2020 Strategy of a smart, sustainable and inclusive growth, which is the main challenge for this programming period.

The regional policy for the programming period of 2014-2020 is of particular role and significance. This is due to the series of challenges Europe is to face in the light of the global crisis that has begun in 2008, and although numerous economic indicators now exhibit a positive trend, there is still a recovery time required. In the vein of striving for a crisis-resistant Europe there emerged the need for a more efficient regional policy that would contribute to creating more competitive and resilient regions.

The total budget, intended for the purpose of regional policy for the programming period of $2014-2020$, is $€ 376$ billion, meaning about $8 \%$ of increase comparing to the previous period. The main assumption for 2014-2020 was to achieve the Europe 2020 objectives consisting of:

- Smart growth

- Growth for all

- Sustainable growth.

These objectives include raising the employment rate, overcoming poverty, improving access to education, investing more financial means in research and technology, using energy more efficiently and promoting clean technologies to reduce carbon dioxide emission.

In the current programming period the number of eligible regions has increased. The regional policy is addressed at three categories of regions: less developed regions (with a GDP below 75\% of EU average, and with Cohesion Fund budget of $€ 162.6$ billion), transition regions (with a GDP between $75 \%$ and $90 \%$, fund allocation being at $€ 39$ billion). The last category encompassed regions of more than $90 \%$ of UE average GDP (with $€ 53.1$ billion). Current regional policy of 2014-2020 is intended to support the process of economic transition more efficiently. A significant innovation is that the share of the European Social Fund (ESF) has increased to reach $25 \%$ of total budget, in comparison to $22 \%$ for the $2007-2013$ programming period.

The 2014-2020 programming period brings a series of new, promising qualities to the regional policy of the European Union, which are the result of long and difficult negotiations. The main ones include:

1. Increasing the absorption level of cohesion funding

2. More focus will be put on the EU's less developed regions and Member States

3. Increasing the Thematic Concentration of Resources. The beneficiaries are to concentrate their resources on a restricted number of thematic objectives linked to the Europe 2020 Strategy. Moreover, the transition and more developed countries are required to direct $20 \%$ of financial means to energy efficiency and renewable energy and $80 \%$ to SME competitiveness and innovation

4. A stronger focus on results aiming for a more effective policy evaluation. A more resultsoriented approach will be supported. Moreover, the date monitoring of policy's outputs will be enhanced with annual reporting

5. Reduction of administrative burden. Possibility for implementation of multifund programmes combining ERDF, ESF and Cohesion Fund 
6. The involvement of local and regional stakeholders as well as social partners and civil society organizations in the implementation of operational programmes will be increased. Local development approaches based on partnerships among the various relevant actors will be supported.

By implementing the qualities listed above, it is anticipated that the regional policy in its current shape shall contribute to the more efficient reduction of socio-economic polarization across Europe. It must be stated, though, that although the budget has generally increased in comparison to the previous programming period, so have the regions' needs and challenges as many of them have been seriously affected by the global crisis. Weakness of socio-economic performance also applies to regions, to which regional policy's intervention was not addressed before. This is evidenced by an unprecedented decrease in GDP level of numerous EU's regions registered in the period of 2007-2010 (Fig. 5.) and, according to ESPON regional typology (2013), a vast majority of Europe's regions have still not recovered from the economic crisis, including the ones that did not appear to be at risk (e.g. The Netherlands, northern France, UK, northern Italy). Many regions of the new member states (that joined the EU in 2004 and 2007) have also registered a decrease in GDP level and a large part of them has still not recovered in response to crisis. Such a course of events seems to be confirming the further deepening of disparities between the Western and Eastern Europe at regional level. Moreover, as the European Union has expanded by a new member state in 2013, at the end of previous programming period (Croatia), it is expected that a significant share of available funds shall be directed there. It is thus to be believed that restructuring and simplifications, which are assumed for the 2014-2020 EU's regional policy shall contribute to making it a more effective tool for overcoming regional disparities.

Response to Crisis

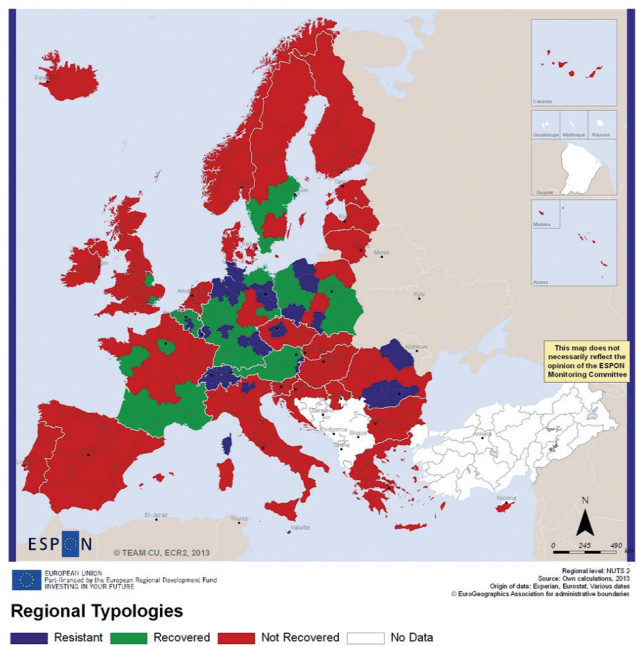

Growth of GDP in real terms, 2007-2010

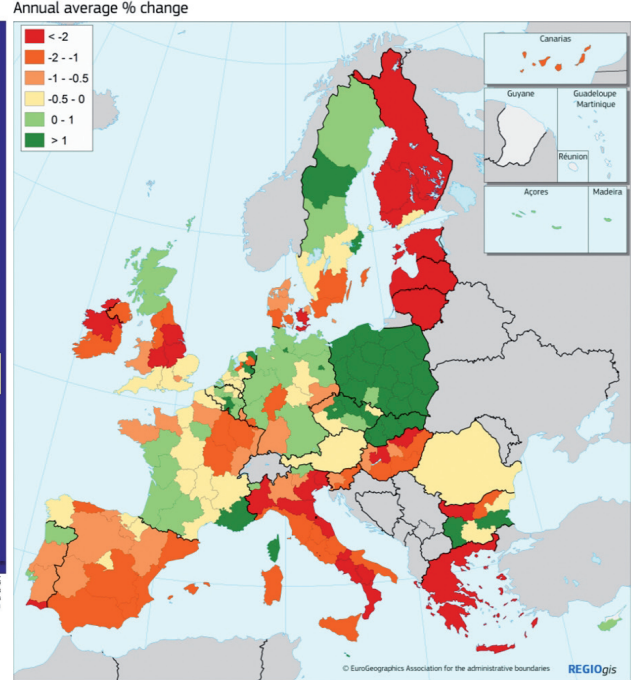

Fig. 5. Response to crisis - ESPON regional typology (on the left, 2013) and growth of GDP in real terms in 2007-2010, annual average change as percentage (on the right). Source: ESPON 2013 and RegioGIS from ESPON Dublin Seminar presentations (2013) 


\section{Evaluation of regional policy by ESPON}

The European Spatial Planning Observation Network (ESPON) within the broad spectrum of analyzed issues has also undertaken the evaluation of regional policy. More specifically, the ESPON Programme under the 2.2.1 project examined the territorial effects of structural funds, whereas the 2.2.3 project was devoted to territorial effects of structural funds in urban areas.

The 2.2.1 project analyzed the nature and effect of regional policy's structural funds from the point of view of territorial cohesion and polycentricity, sector-specific differences and knowledge needs. In the light of these aspects, the authors of evaluation proved that in the programming period of 1994-1999, 17\% of the funds, which were intended for the development of polycentricity were addressed to the already polycentric areas, whereas $41 \%$ went to areas, in which polycentricity is not likely to occur (ESPON 2.2.1 Final Report 2005). Therefore, an adverse trend in addressing the structural funds was shown. On the other hand, the ESPON project proved that, in general, spending coincides with negative population development and poor accessibility. In terms of enhancing territorial cohesion, according to ESPON 2.2.1, the results of intervention within the structural funds are regarded as contradictory across the scales of analysis: at a cross-border scale there is an overall decrease of territorial cohesion, while when examined at micro or local scale territorial cohesion shows an increase. Similarly, cross-border cohesion in the regional dimension was enhanced in contrast to the decline of interregional cohesion in general (ESPON 2.2.1 Final Report 2005).

The ESPON 2.2.3 project was devoted to territorial effects of structural funds in urban areas. The main assumption was to determine indicators and methods, which would be appropriate for identifying urban areas across the EU that might be eligible for Objective 2 like programmes in the future, aiming at supporting the economic and social conversion of areas experiencing structural difficulties. For this purpose a new typology of urban areas was developed, which, due to the use of comparable datasets, would enable robust comparisons across the European territory (ESPON 2.2.3 Final Report 2003).

\section{Criticism of regional policy}

Despite its constant evolution and evident improvement, some authors dealing with the subject have recognized weaknesses of EU regional policy. The most frequently mentioned criticisms are that the regional policy has developed into a 'catch-all' policy, lacking a clear mission, insufficiently focused on growth, with inadequate policy instruments, being excessively complex and too bureaucratic to administer (Manzella, Mendez 2009). By its nature, EU regional policy imposes specific legal and organizational solutions on the member states and candidates. The policy allocates public means to certain investment priorities that do not always correspond to developmental issues of a given country. On a regional level, accessing the structure of the European single market leads to the increase of economic competitiveness between regions. This, in case of numerous units with lower performance, despite the policy's support might foster the risk of their further marginalization (Grosse, 2004). Moreover, some scientists dealing with the issues of EU regional policy claim that one of its principle, namely territorial convergence, is hardly, if at all achievable (Gorzelak 2012). At this point it also needs to be emphasized that the process of fulfilling the objectives of development programs and effective implementation of actions planned encountered significant obstacles by policy-makers. Despite its weak points, it is however widely accepted that European Cohesion Policy has made a 
substantial contribution to increased cohesion across Europe in terms of policy approach, what is commonly referred to as the value added of European regional policy (Poverari, McMaster 2005).

\section{Conclusion}

Regional policy of the European Union, and earlier the European Economic Community have since 1957 passed through a number of stages, which were characterized by diversified approaches as well as scale of operation. However, in general, these phases were characterized by a common goal, namely - to reduce regional disparities throughout Europe. Despite numerous opinions that the EU regional policy is not - and perhaps will never become - an ideal endeavor, it cannot be denied that in over 50 years it has evolved into a more smoothly functioning mechanism, involving a growing number of European regions and operating with increasingly larger financial means. Over time, in subsequent programming periods, there has been a significant shift in approach in the process of regional policy formation. The regional needs and issues are more effectively identified in the light of the changing reality and new challenges emerging. More emphasis is placed on the territorial aspects, including endogenous regional potential that, if enhanced appropriately, leads to socio-economic development. The regional and local policymakers are increasingly involved in the process of shaping the EU policy contributing to a complementary action of policies at various levels. The voices for regional policy's imperfections, pertaining to its inadequate management and planning could be confronted with a real, tangible aid for regions lagging behind, especially in the case of new EU members (countries that joined in 2004 and later), in whose eligible regions the role and significance of the regional policy seems to be the highest. This might be clearly evidenced by new roads, wastewater treatment plants, new computers at schools, and thousands of other undertakings financed or co-financed by the EU. For this reason, the regional policy can be considered as one of the major pillars constituting Common Europe. This is especially important considering the fact that numerous UE member states were once at the other side of the "Iron Curtain" and through implementing the EU 's regional policy the concept of Common Europe is now becoming tangible and realistic. The policy is an evolving intervention equipped with progressively more efficient instruments and increasing budget allocations, which allow for approaching the social, economic and territorial cohesion of the European Union. Nevertheless, at this point it must be emphasized that apart from the amount of financial input, the way and efficiency of allocating funds and expenditures is equally or perhaps even more important. This relies to a great extent on the approach of regional authorities in the management of financial means and also appropriate identification of the most pressing needs. Altogether, as having been a steadily improved 'tool' for reducing regional disparities during over half a century, the EU regional policy may become a valuable inspiration to the non-EU countries.

\section{References:}

Artobolevskiy, S.S., 1997, Regional Policy in Europe, Regional Studies Association No 11, Routledge, Abingdon, 192 pp.

Bachtler J., Yuill D., 2001, Policies and Strategies for Regional Development: A Shift in Paradigm?

Regional and Industrial Policy Research Paper 46, European Policies Research Centre University of Strathclyde, Glasgow, 41 pp. 
Chudy-Hyski D., 2009, Regional Policy in Poland and its importance for Development Policy, Infrastructure and Ecology of Rural Areas No 7/2009, Commission of Technical Rural Infrastructure, Polish Academy of Sciences, Cracow, pp. 79-91.

Consolidated version of The Treaty on European Union and of The Treaty Establishing The European Community, Article 2.

ESPON 2.2.1 Territorial Effects of the Structural Funds. Final Report. Presentation at the ESPON seminar 17-18 May 2005 Consortium: Nordregio/Stockholm, Mcrit/Barcelona, EPRC/Glasgow, Infyde/Bilbao, ITPS/Stockholm, Systema/Athens, University of Utrecht, Margaret Hall Consulting and Peter Ache Consulting.

ESPON 2.2.3 Territorial Effects of the Structural Funds in Urban Areas. Final Report, 2003.

ESPON Malmo Report, 2010, Regional Use of ESPON Knowledge, 2010, Working Paper from the internal ESPON Seminar 3-4 December 2009 in Malmö. http://www.espon.eu/export/sites/default/ Documents/Publications/SeminarsReports/Malmoe_Seminar_Report.pdf [10 February 2014].

European Funds, http://www.funduszeeuropejskie.gov.pl/ [10 February 2014].

Faludi A., 2009, A turning point in the development of European spatial planning? The 'Territorial Agenda of the European Union' and the 'First Action Programme' Progress in Planning 71, pp. 1-42.

Gorzelak G., 2012, Cohesion Policy and the Challenges for the Future, in: Evaluating the effects of regional interventions. A look beyond current Structural Funds' practice, Ministry Of Regional Development, Warsaw, pp. 25-33.

Grosse T.G., 2004, Polityka regionalna Unii Europejskiej. Przykład Grecji, Włoch, Irlandii i Polski, Instytut Spraw Publicznych, Warszawa, 362 pp.

Hague, C., 2005, ESPON and Territorial Research in Practice, European Territorial Research in Progress. Conference Proceedings of the 1st ESPON Scientific Conference, pp.23-35.

Kozak, M.W., 2012, Strategic planning of regional development, in: Evaluating the effects of regional interventions. A look beyond current Structural Funds' practice, Ministry Of Regional Development, Warsaw, pp. 34-54.

Manzella, G.P., Mendez C., 2009, The turning points of EU Cohesion Policy, An Agenda for a reformed Cohesion Policy, $28 \mathrm{pp}$.

Misiąg, J., Misiąg, W., Tomalak M., 2013, Ocena efektywności wykorzystania pomocy finansowej Unii Europejskiej jako instrumentu polityki spójności spoleczno-gospodarczej oraz poprawy warunków życia, Wyższa Szkoła Informatyki i Zarządzania z siedzibą w Rzeszowie, Rzeszów, $146 \mathrm{pp}$.

Official website of the European Union, http://www.europa.eu/ [1 February 2014].

Olechnicka A., Wojnar K., eds., 2013, Terytorialny wymiar rozwoju. Polska z perspektywy badań ESPON, Krajowy Punkt Kontaktowy ESPON \& Authors, Centrum Europejskich Studiów Regionalnych i Lokalnych EUROREG, Warszawa, 130 pp.

Poverari L., McMaster I., 2005, Territorial Cohesion and New Cohesion Policy: Challenges for Old and New Member States, Paper presented at 1st ESPON Scientific Conference, Luxembourg, Luxembourg.

Sapir A., Aghion P., Bertola G., Hellwig M., Pisani-Ferry J., Rosati D., Vińals J., Wallace H., Buti M., Nava M., Smith P.M., 2003, An Agenda for a growing Europe. The Sapir Report, Oxford University Press, 236 pp. 
http://rcin.org.pl 